\title{
Tayangan Video Animasi “Si Nopal” Untuk Mendukung Interaksi Sosial Siswa Sekolah Dasar
}

\author{
Ghafiruna Al Aziz, Chumi Zahroul Fitriyah, Zetti Finali \\ ghafiruna2015@gmail.com, chumi.fkip@unej.ac.id, zetti.fkip@unej.ac.id \\ Pendidikan Guru Sekolah Dasar, Fakultas Keguruan dan Ilmu Pendidikan, Universitas Jember
}

"Si Nopal" Animated Video to Support Elementary School Students'Social Interaction

\begin{abstract}
Social interaction is a dynamic social relationship that involves relationships between individuals, between groups, and between individuals and groups. The purpose of this research is to analyse an animated film "Si Nopal" in supporting social interaction of the elementary students. The type and design of the study used in this study is descriptive research. The data collection methods are documentation and interviews. Qualitative data analysis used in this study consisted of three activity processes, namely data reduction, data presentation, and drawing conclusions. Based on the results and discussion it can be seen that the Nopal's animated video can support students' social interactions. The social interactions in the Nopal animated video include the communication process, social contact, and associative processes. Students who are given the animated video show "Si Nopal" have the motivation to imitate the aspects of social interaction in the video shown.
\end{abstract}

Keywords: Animation Video, Social Interaction, Elementary School

Received date: 6 Maret 2020

Article Info

Revised date: 11 Agustus 2020 Accepted date: 24 September 2020

\section{PENDAHULUAN}

Perkembangan teknologi informasi dan komunikasi (TIK) di era revolusi industri 4.0 yang semakin pesat menyebabkan perubahan pada berbagai aspek kehidupan manusia. Perkembangan TIK tersebut dapat mempengaruhi setiap aspek kehidupan manusia tidak terkecuali dalam bidang pendidikan (Harfiyanto, Utomo, \& Budi, 2015). Banyak media TIK yang digunakan untuk meningkatkan berbagai aspek pendidikan sosial dalam pembelajaran. Penggunaan TIK dalam bidang pendidikan dapat menjadi alat strategis dalam membelajarkan pendidikan sosial siswa meliputi merubah pola pikir, perilaku, dan tindakan siswa (Pebriana, 2017).

Menurut Sudjana (2009), proses pendidikan terjadi dalam situasi interaksi sosial, yakni interaksi antar manusia, dan interaksi manusia dengan lingkunganya. Interaksi sosial merupakan hubungan-hubungan sosial yang dinamis yang menyangkut hubungan antara orang-orang perorangan, antara kelompok-kelompok manusia, maupun antara orang perorangan dengan kelompok manusia (Brungin, 2009; Soekanto, 2017). Bentuk interaksi sosial tidak hanya bersifat kerjasama, tetapi juga bisa berbentuk persaingan, pertikaian dan sejenisnya. Interaksi sosial adalah kunci dari semua kehidupan sosial. Tanpa adanya interaksi sosial tidak akan mungkin ada kehidupan bersama. Oleh karena itu, interaksi sosial sangat penting dikembangkan dan diajarkan sedini mungkin di jenjang Sekolah Dasar (SD) untuk menunjang kemampuan sosial peserta didik.

Sekolah Dasar merupakan pondasi awal dalam pendidikan formal tetapi juga terbatas kepada pengembangan kemampuan akademik siswa untuk mempersiapkan diri pada jenjang yang lebih tinggi. Kemampuan sosial siswa SD akan berkembang seiring dengan pola hubungan dengan sesama peserta didik maupun dengan warga sekolah lainnya dalam bentuk interaksi sosial.

Salah satu media TIK yang sangat umum digunakan dalam membelajarkan pendidikan sosial adalah media video animasi (Bakhtiar, 2015; Muslimin, 2012; Kurniawan, 2016). Menurut Gilang, Sihombing, \& Sari (2018) faktor yang dapat mempengaruhi pembentukan perilaku-perilaku anak usia SD adalah faktor percontohan dari keluarga, lingkungan bermain, dan lingkungan media sosial. Media video animasi dapat digunakan sebagai pemberian contoh interaksi sosial yang baik bagi siswa. Bandura (dalam Ainiyah, 2017) menyatakan bahwa eksperimennya yang terkenal dengan istilah boneka Bobo, 
menyatakan bahwa anak-anak belajar dan meniru perilaku-perilaku yang mereka amati dilakukan oleh orang lain. Anak-anak dalam observasi ini mengamati (Film) dimana terdapat banyak adegan seseorang melakukan kekerasan terhadap boneka Bobo. Anak-anak tersebut mulai meniru tindakan-tindakan agresif yang telah mereka amati sebelumnya dilakukan oleh orang dewasa. Pengaruh video animasi yang suka mempertontonkan kekerasan, bicara kotor terhadap interaksi sosial pada anak usia dini ternyata memberikan pengaruh negatif bagi tontonan bagi peserta didik. Seringkali siswa berinteraksi dengan video animasi dan juga dunia maya kemudian mempengaruhi daya pikir dan tindakan terhadap kehidupannya sehari-hari. Video animasi yang buruk juga secara signifikan dapat mempengaruhi interaksi sosial anak terhadap lingkungan terdekatnya (Sitinjak, Hasyim, \& Yanzi, 2017). Selain itu anak juga merasa asing, kurang peka dan bahkan tidak perduli terhadap lingkungannya. Hal ini tentunya sangat membahayakan perkembangan sosial pada peserta didik. Perlu diberikan pemahaman yang baik kepada anak untuk lebih selektif dalam memilih tontonan video atau aplikasi yang terdapat di dalamnya berupa proses edukasi interaksi. Oleh karena itu, dibutuhkan analisis lebih lanjut terhadap film atau animasi yang beredar dan dilihat oleh anak-anak agar pendidik dapat lebih selektif dalam memilih tontonan yang tepat.

Peran seorang pendidik adalah menumbuhkan pemahaman siswa agar lebih selektif terhadap tontonan video animasi yang mengandung konten berkualitas sehingga dapat meningkatkan interaksi sosial yang dimiliki siswa. Selain itu, guru juga bisa menggunakan video atau film animasi yang berkualitas untuk mendukung interaksi sosial agar menarik perhatian siswa, mengganti fitur yang biasanya bermain permainan di gadget dan memberikan kesan serta pemahaman tersendiri di ingatan atau kehidupan siswa itu sendiri. Apabila kita memberikan video animasi yang menarik perhatian siswa, sehingga siswa diharapkan lebih berinteraksi dengan lingkungan di sekitar serta peduli dengan lingkungan sekitar. Saat ini sudah banyak video animasi karya anak bangsa yang sudah dikembangkan guru sebagai salah satu alternatif bahan pembelajaran. Selain sebagai media hiburan, film animasi juga berfungsi sebagai media penanaman untuk mendukung interaksi sosial dan pembentuk kepribadian anak (Purnamasari, 2020). Penggunaan video animasi merupakan salah satu alternatif yang bisa meningkatkan interaksi sosial anak. Selain itu interaksi sosial yang ada di dalam film tersebut diharapkan bisa mampu membentuk kepribadian yang suka berinteraksi dengan teman, keluarga dan juga lingkungan sekitar. Interaksi inilah yang sangat penting ditanamkan kepada siswa, karena dalam hidup bermasyarakat kelak siswa tidak hanya mampu menguasai bidang keilmuan namun juga harus memiliki interaksi sosial yang baik.

Video animasi yang akan diambil sebagai bahan penelitian adalah video animasi "Si Nopal". Penggunaan film animasi sebagai bahan penelitian dikarenakan film tersebut menarik, menceritakan keseharian anak-anak, bahasa yang digunakan juga mudah dipahami dan unik. Selain itu, video animasi atau yang sering disebut kartun adalah tontonan yang sangat digemari anak-anak Indonesia. Sebuah penelitian menyebutkan bahwa rata-rata anak usia sekolah dasar menonton tayangan kartun antara 30 hingga 35 jam setiap minggu atau menghabiskan waktu paling lama di depan televisi sekitar 5 sampai 6 jam setiap harinya (Triwardani \& Wicandra, 2007). Pembuatan animasi "Si Nopal" bermula sebagai perwujudan dari sang pembuat film animasi yang berusaha menggambarkan dinamika dunia kehidupan anak-anak hingga remaja. Si Nopal sangat diminati oleh masyarakat Indonesia bahkan tokoh "Si Nopal" dan "cute girl" kini menjadi tokoh animasi yang ikonik karena bentuk dan tingkah kocaknya. Film animasi tersebut sangat mudah diakses oleh kalangan masyarakat karena sudah ada di Youtube dan memiliki 5.86 juta subscriber pada tahun 2020. Pemilihan video animasi "Si Nopal" dalam penelitian ini didasarkan karena di dalam animasi tersebut menggambarkan cerita tentang tingkah laku jenaka yang banyak memuat interaksi sosial antara anak, orang tua, siswa dengan guru serta karakter lainnya yang dapat digunakan sebagai nilai pendidikan.

Interaksi sosial yang terkandung dalam film animasi tersebut bisa digunakan untuk mendukung interaksi sosial pada siswa SD. Mengacu pada uraian tersebut, nantinya guru akan memperlihatkan video animasi dan diharapkan siswa mampu mengamati video animasi untuk mendukung perkembangan interaksi sosialnya ke arah yang lebih positif dan dapat mengimplementasikan interaksi yang positif tersebut di dalam kehidupan sehari-hari. Kegiatan menganalisis animasi si Nopal ini juga sebagai antsipasi kepada siswa yang dimaksudkan agar mereka selalu berinteraksi dengan lingkungan sekitarnya dan menjadikan tontonan yang bermanfaat.

Berdasarkan uraian latar belakang yang telah dipaparkan tersebut, maka penelitian ini bertujuan untuk menganalisis film animasi "Si Nopal" untuk mendukung interaksi sosial pada siswa SD. 


\section{KAJIAN PUSTAKA}

Menurut Pebriana (2017), interaksi sosial dapat diartikan sebagai hubungan yang terjadi dalam sekelompok individu yang saling berhubungan baik dalam berkomunikasi maupun melakukan tindakan sosial. Interaksi sosial merupakan pula salah satu prinsip integritas kurikulum pembelajaran yang meliputi keterampilan berkomunikasi, yang bekerja sama yang dapat untuk menumbuhkan komunikasi yang harmonis antara individu dengan lingkungannya (Hernawan, 2010). Beberapa penelitian terdahulu telah banyak mengungkapkan bahwa interaksi sosial memiliki hubungan positif terhadap hasil belajar siswa (Ginting, Asiah, \& Nasution, 2019; Mertani, Latief, \& Utaminingsih, 2015; Nuraida, Halimah, \& Rokhayati, 2014; Melchioriyusni, Zikra, \& Said, 2013; Oktaviani, Yusmansyah, \& Rahmayanthi, 2013). Oleh karena itu, aspek interaksi sosial hendaknya mendapat perhatian lebih agar dapat memaksimalkan hasil belajar sekaligus kemampuan bersosial siswa.

Interaksi sosial anak bersifat dinamis dan berkembang seiring perkembangan usianya. Cara yang dapat digunakan untuk membantu mengembangkan interaksi sosial anak adalah melalui percontohan (Nunik, 2013). Percontohan dapat dilakukan siswa melalui proses belajar menjadi pengamat, pendengar, dan pemikir di kelas melalui keterlibatan aktif (Alvermann \& Phelps, 2005; Vacca, Vacca, \& Mraz, 2011). Routman (2005) berpendapat bahwa siswa belajar lebih banyak ketika mereka dapat secara aktif terlibat berbicara satu sama lain. Interaksi sosial terjadi di setiap proses pendidikan di banyak kegiatan belajar mulai jenjang SD hingga perguruan tinggi, baik dengan model interaksi siswa dengan guru, siswa dengan teman, maupun siswa dengan lingkungan hidup (Hurst, Wallace, \& Nixon, 2013).

Menurut Soekanto (2013), salah satu faktor yang mendasari terbentuknya pola interaksi sosial pada anak adalah peniruan (Imitation), dimana anak dapat terdorong untuk mematuhi kaidah atau nilainilai yang baik dalam berinteraksi sosial karena hasil meniru dari suatu contoh. Berdasarkan hal tersebut dapat diketahui bahwa, untuk membiasakan siswa dengan interaksi sosial yang baik guru hendaknya menciptakan lingkungan pembelajaran yang kaya dengan suri tauladan agar bisa siswa tiru dalam proses berinteraksi dalam kesehariannya.

Media memiliki peran penting untuk membentuk karakter dan pola interaksi anak. Perkembangan teknologi dan media yang sangat pesat dapat mengubah pola interaksi sosial siswa dalam proses pembelajaran (Harfiyanto, Utomo, Budi, 2015). Menurut Budiman (2016), media elektronik dan media sosial memiliki pengaruh yang kuat terhadap pembentukan pola interaksi anak karena anak cenderung mencontoh hal-hal yang sering dilihatnya. Menurut Triwardani \& Wicandra (2007) dalam konteks proses sosialisasi nilai dan pembelajaran, aktivitas menonton tayangan kartun dapat dikatakan sebagai salah satu interaksi sosial yang terjadi pada anak-anak. Dalam melihat film animasi kartun, sebagian besar anak-anak cenderung akan menirukan apapun yang dilakukan oleh karakter film animasi kartun tersebut (Purnamasari, 2020). Oleh karena itu, dalam upaya pembentukan interaksi sosial anak secara optimal diperlukan upaya untuk menganalisis kualitas tayangan kartun baik yang dilihat pada keseharian siswa maupun yang akan digunakan dalam media pembelajaran.

interaksi sosial yang dianalisis dalam penelitian ini merupakan dialog yang bermakna di antara dua atau lebih orang yang terdapat dalam video animasi "Si Nopal" yang dapat digunakan sebagai pembelajaran interaksi sosial siswa. Aspek Interaksi sosial yang akan dianalisis dalam video aniamasi "Si Nopal "ini meliputi: (1) aspek kontak sosial seperti cara berbicara dan bertatap muka dengan pihak lain (Basrowi, 2005); (2) proses komunikasi seperti pembicaraan, gerak-gerik fisik ataupun nuansa perasaan yang tercipta dari proses interaksi (Basrowi 2005); dan (3) proses asosiatif seperti terbentuknya interaksi yang positif misalnya kerjasama dan diskusi (Soekanto, 2017).

\section{METODE PENELITIAN}

Jenis dan rancangan penelitian yang digunakan dalam penelitian ini adalah jenis penelitian deskriptif. Penelitian ini membahas mengenai deskripsi interaksi sosial yang terdapat dalam video animasi Si Nopal. Penelitian deskriptif adalah penelitian yang berusaha untuk mendeskripsikan suatu keadaan, suatu kondisi secara ilmiah, maksudnya yaitu agar diperoleh suatu gambaran yang jelas, objektif, dari suatu keadaan sebagaimana adanya tanpa menghubungkan dengan keadaan dan kondisi tertentu maupun variabel lainya. Sedangkan untuk mengetahui respon siswa terhadap tayangan animasi "Si Nopal", penelitian ini menggunakan studi kasus sederhana terhadap anak-anak usia Sekolah Dasar yang telah melihat lebih dari 10 episode animasi "Si Nopal" untuk mengetahui pola interaksi sosial 
yang mereka lakukan. Penelitian ini bertujuan untuk mendiskripsikan interaksi sosial yang terdapat dalam video animasi Si Nopal dan pengaruhnya pada pola interaksi sosial anak. Hasil dari penelitian deskriptif kualitatif berupa pemaparan mengenai situasi yang diteliti yang disajikan dalam uraian naratif. Oleh karena itu, data yang diperoleh berasal dari data kualitatif yang berupa deskripsi wawancara, hasil observasi, dan hasil dokumentasi naskah video.

Data yang digunakan pada penelitian ini berupa kalimat-kalimat pada dialog (naskah) serta sikap yang ditunjukan oleh para tokoh pada video animasi "Si Nopal". Sumber data pada penelitian ini adalah video dengan total keseluruhan 10 episode video animasi "Animasi Nopal" yang diunduh melalui laman Youtube.com. Untuk mengetahui respon anak usia SD setelah diberikan tontonan "Animasi Nopal", penelitian ini menggunakan studi kasus sederhana pada 2 subjek penelitian. Subjek penelitian ini adalah dua anak yang berusia antara 11 tahun sampai 12 tahun yang berada di SDN Tunjung 02 Lumajang karena anak pada usia ini masih pada masa imitasi atau meniru keadaan yang ada di lingkungan maupun sesuatu yang dilihatnya, selain itu anak pada usia tersebut masih memiliki waktu menonton yang sangat tinggi sehingga memungkinkan banyak sekali tontonan yang bisa dia lihat dalam sehari. Kajian penelitian ini nantinya mencakup tentang interaksi sosial yang terdapat dalam video animasi Si Nopal tersebut yang bisa mendukung interaksi sosial yang ada pada anak.

Metode pengumpulan data yang dipakai dalam penelitian ini adalah dokumentasi dan wawancara. Pengumpulan data menggunakan metode dokumentasi pada penelitian ini digunakan untuk menjawab rumusan masalah dengan mengunduh video animasi si Nopal melalui situs laman YouTube.com pada tahun 2019. Kegiatan analisis data hasil dokumentasi dilakukan menggunakan bantuan instrumen tabel pedoman pengumpulan data dan tabel pedoman analisis data yang telah disiapkan. Metode wawancara semi terstruktur dipakai untuk mengetahui respon siswa yang telah diberi tontonan animasi "Si Nopal". Metode wawancara dilakukan dengan bantuan instrumen pedoman wawancara.

Analisis data kualitatif yang digunakan dalam penelitian ini terdiri atas tiga proses kegiatan yaitu reduksi data, penyajian data, dan penarikan kesimpulan (Miles dan Huberman dalam Sugiyono, 2015:246). Proses analisis data diuraikan berikut: (1) proses reduksi data, mereduksi data dalam penelitian ini bertujuan untuk memfokuskan pada data tulisan, baik berupa kata-kata, kalimat-kalimat, sikap dan perilaku para tokoh yang dianggap penting. Data yang dimaksud adalah data yang mengandung interaksi sosial; (2) penyajian data dalam penelitian ini adalah pengklasifikasian data, pengkodean data, pendeskripsian data dan interpretasi data. Pengklasifikasian data dilakukan denga cara mengkelompokkan data yang berupa kata-kata, kalimat, sikap dan perilaku dalam video animasi Si Nopal yang diindikasi mengandung interaksi sosial. Data yang sudah dikategorikan kemudian diberi kode kontak sosial (KS), Proses Komunikasi (PK), proses asosiatif (AS); (3) Penarikan kesimpulan, penarikan kesimpulan atau verifikasi data dilakukan oleh peneliti terhadap suatu dokumen yang menajdi objek penelitian. Hasil analisis akan ditarik kesimpulan secara umum, setelah melakukan penarikan kesimpulan, peneliti harus mengecek kembali pada tahap reduksi data dan penyajian data untuk memastikan tidak ada kesalahan yang dilakukan.

\section{HASIL PENELITIAN DAN PEMBAHASAN}

Berdasarkan data yang terkumpul pada 10 episode video animasi konten anak "Si Nopal" yang diteliti, di antaranya yaitu episode: Akibat Tidak Cuci Tangan Sebelum Makan, Cita-Cita Cute Girl Debat Si Nopal Vs. Cute Girl! Siapa Yang Menang, Lagu Libur Sekolah, Robot Aneh, Lagu Kemerdekaan Versi Cute Girl, Lagu Semangat Sekolah Yang Aneh, Nilai Ulangan, Kehebatan Cute Girl yang Tidak Banyak Orang Tahu dan Berkemah. Terdapat beberapa interaksi sosial yang dicontohkan dalam video animasi tersebut. Interaksi sosial dalam penelitian ini yaitu Kontak Soial (Sosial contact), Komunikasi dan asosiatif. Berikut merupakan data serta penjelasan interksi sosial yang ada pada video animasi "Si Nopal".

\section{Kontak sosial}

Basrowi (2005) mengatakan kontak sosial secara langsung yang berindikasi cara berbicara misalnya bertatap muka dengan pihak lain. Video animasi dengan episode Lagu Libur Sekolah tedapat pula paparan data dengan menunjukan indikasi kontak sosial. Berikut salah satu contoh naskah animasinya. 


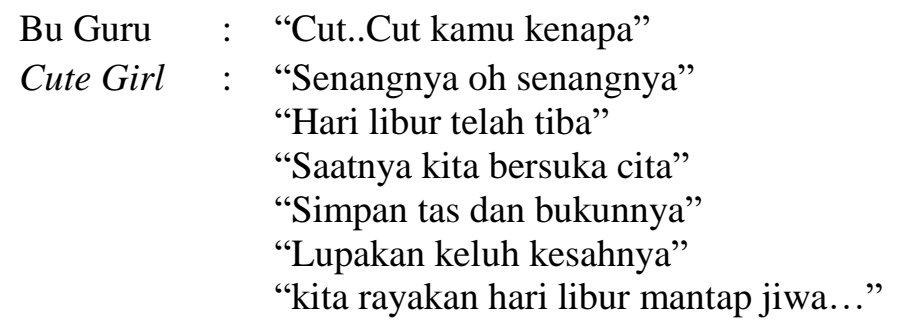

Data tersebut menunjukkan bahwa pada saat Cute Girl memberikan penampilan di dalam kelas sontak membuat siswa lain melihat si Cute Girl. Respon positif bagi siswa lain agar menikmati sebuah momen liburan. Hal ini menunjukan indikator dari interaksi sosial yaitu kontak sosial.

\section{Proses Komunikatif}

Basrowi (2005) mengatakan komunikasi sosial dapat diwujudkan dengan pembicaraan, gerakgerik fisik ataupun perasaan. Interaksi juga perilaku sosial yang berlangsung antara dua orang atau lebih. Video animasi dengan episode "Akibat Tidak Cuci Tangan Sebelum Makan" tedapat pula paparan data dengan menunjukan indikasi kontak sosial. Berikut salah satu contoh cuplikan naskah animasinya.

$\begin{array}{lll}\text { Bunda } & : & \text { "Bunda akan kasih tahu cara cuci tangan yang baik dan } \\ & \text { benar" (Dengan nada memberi tahu) } \\ \text { Nopal } & : \text { "Bagaimana caranya?" (Tanya si Nopal kepada si Bunda) } \\ \text { Bunda } & : \text { "Pertama, basahi tangan dengan air mengalir, ambil sabun, } \\ & \text { gosok di telapak tangan lalu punggung tangan dan sela-sela } \\ & \text { jari secara bergantian. Bersihkan jari dengan mengatup dan } \\ & \text { mengggosok ke telapak tangan secara bergantian. Bilas } \\ & \text { dengan air bersih. Terakhir, keringkan dengan handuk, lap } \\ & \text { atau tisu bersih. Nah sekarang giliran kammm" }\end{array}$

Data tersebut menunjukkan bahwa Nopal bertanya kepada Bunda cara untuk cuci tangan kemudian Bunda menjelaskan dengan rinci sehingga mudah dimengerti oleh si Nopal. Dampak dari tidak mencuci tangan yaitu penyakit diare. Hal ini menunjukan indikator dari interaksi sosial yaitu proses komunikasi.

Proses asosiatif

Soekanto (2017) asosiatif proses mengarah pada interaksi yang positif bukan pada arah negatif. Interaksi asosiatif sangat perlu bagi perkembangan peserta didik. Berikut beberapa episode video animasi si Nopal yang mengandung proses asosiatif yakni berjudul "Cita-Cita Cute Girl" sebagai berikut.

Siswa : :Hai cuty. Anaknya Abah Enol Rampampam bagaimana kamu bisa melawan ketidak adilan, apakah kamu punya kekuatan? Ah aku tahu pasti kekuatan menghayal kan Cuty?"

$\begin{array}{lll}\text { Siswa } & : & \text { "Eeee. Kekuatan kata-kata." } \\ \text { Siswa satu } & : & \text { "Kata-kata katanya". (sambil meragukan) } \\ \text { kelas } & \text { (Satu kelas kembali tertawa) } \\ \text { Milos } & : & \text { "Lagian ketidak adilan seperti apa yang ingin kamu lawan? } \\ & \text { Kalau di Negara ini sudah ada keamanan dan hukum." } \\ & \begin{array}{l}\text { Satu kelas menanyakan hal yang sama sambil bergemuruh) } \\ \text { Cute Girl }:\end{array} & \text { "Ketidak adilan seperti apa? Seperti kalian yang } \\ & \begin{array}{l}\text { mentertawakan hak sesorang untuk mengemukakan } \\ \text { keinginannya." }\end{array}\end{array}$

Data tersebut menunjukkan bahwa Cute Girl Mampu untuk menyelesaikan permasalahan sehingga tersampaikan pesan dan tindakan yang positif. Cute Girl mengungkapkan perasaannya tentang "ketidakadilan" seperti apa? seperti kalian yang mentertawakan hak sesorang untuk mengemukakan keinginannya" dengan demikian tercipta penyelesaian permasalahan jika terjadi tindakan Bullying. Hal ini menunjukan indikator dari interaksi sosial yaitu proses asosiatif. Terdapat juga video animasi si Nopal yang mengandung proses asosiatif pada episode Lagu Kemerdekaan Versi Cute Girl" data sebagai berikut. 
Tayangan Video Animasi "Si Nopal” Untuk Mendukung Interaksi Sosial Siswa Sekolah Dasar (Ghafiruna Al Aziz, Chumi Zahroul Fitriyah, Zetti Finali)

\begin{tabular}{|c|c|}
\hline Cute Girl & $\begin{array}{l}\text { : "Abang aku denger, Abang lagi kesusahan ngerjain RP } \\
\text { yah?" (Tanya Cute Girl) }\end{array}$ \\
\hline Nopal & : "PR" (Jawab Nopal) \\
\hline Cute Girl & $\begin{array}{l}\text { "Jangan risau duhai Abang tetaplah semangat seperti } \\
\text { pahlawan Indonesia yang berjuang mengusir penjajah. } \\
\text { Merdeka!" }\end{array}$ \\
\hline Nopal & : "Eeee. Merdeka" (Jawab Nopal) \\
\hline Cute Girl & $\begin{array}{l}\text { : "Anyway Literally, PR nya pelajaran apa ya Bujank?" } \\
\text { Tanya Cute Girl }\end{array}$ \\
\hline Nopal & "Matematika hehehe" (Jawab Nopal) \\
\hline Cute Girl & $\begin{array}{l}\text { :Tenang Abang, semua pelajaran dapat dikerjakan dengan } \\
\text { instan oleh Robot Pemikir Instan (Dengan menunjukan } \\
\text { Robot). Robot ini mampu mengerjakan PR apa saja karena } \\
\text { kepintaran yang tak terbatas. Ada PR, Robot Pemikir Instan } \\
\text { solusinya" }\end{array}$ \\
\hline
\end{tabular}

Data tersebut menunjukkan bahwa Nopal memberikan motivasi belajar buat si Cute Girl karena permasalahan yang dihadapi oleh Cute Girl yang mendapatkan nilai ulangan jelek. Hal ini menunjukan indikator dari interaksi sosial yaitu asosiatif. Selanjutnya terdapat episode dengan judul "Nilai Ulangan" sebagai berikut:

Cute Girl : "Ini, bang, aku tuh nangis karena nilai ulanganku jelek seperti hati Abang ehe" (sambil menunjukan kertas ulangan)

"Emm, maap Bang. Aku takut Abang marah dan ngehukum aku dengan menyuruhku mencuci pakaian kotor karena tiap Abang marah ke aku pasti berakhir dengan nyuci pakaian kotor"

Nopal : "Lah emang Abang bakal marah kenapa?" (Tanya si Nopal)

Cute Girl : "Eee, karena nilaiku jelek Bang"

Nopal : "Denger ya Cute Girl kesayanganku Abang gak bakal marah dengan pencapaian kamu apapun hasilnya Abang tetap salut dengan kejujuran kamu karena Abang punya prinsip lebih baik dapat nilai jelek daripada bagus tapi nyontek"

Cute Girl : "Eee, tapi nilai itu aku dapat karena nyontek Bang"

Data tersebut menunjukkan bahwa Nopal memberikan motivasi belajar buat si Cute Girl karena permasalahn yang dihadapi oleh Cute Girl yang mendapatkan nilai ulangan jelek. Hal ini menunjukan indikator dari interaksi sosial yaitu asosiatif.

Berdasarkan hasil keseluruuhan video animasi yang telah dianalisis, maka dapat diketahui bahwa dalam video animasi si Nopal terdapat 3 aspek Interaksi sosial yang dapat dilihat pada 10 episode animasi si Nopal tersebut. Diantaranya interaksi sosial yang ada pada setiap episode animasi si Nopal yang telah diteliti yaitu.

Episode "Akibat Tidak Cuci Tangan Sebelum Makan" terdapat interaksi sosial: Proses Komunikasi.

Episode "Cita-Cita Cute Girl" terdapat interaksi sosial: Proses Asosiatif.

Episode "Debat Si Nopal Vs. Cute Girl! Siapa Yang Menang” terdapat interaksi sosial: Proses Komunikasi.

Episode "Lagu Libur Sekolah" terdapat interaksi sosial: Kontak Sosial

Episode "Robot Aneh" terdapat interaksi sosial: Proses Komunikasi.

Episode "Lagu Kemerdekaan Versi Cute Girl" terdapat interaksi sosial: Proses Asosiatif.

Episode "Lagu Semangat Sekolah Yang Aneh" terdapat interaksi sosial: Kontak Sosial

Episode "Nilai Ulangan" terdapat interaksi sosial: Proses Asosiatif.

Episode "Kehebatan Cute Girl yang Tidak Banyak Orang Tahu" terdapat interaksi sosial: Kontak Sosial.

Episode "Berkemah" terdapat interaksi sosial: Proses Komunikasi. 
Hasil analisis yang dilakukan, menunjukan bahwa animasi "Si Nopal" memuat contoh-contoh dari berbagai jenis interaksi sosial yang kemungkinan dapat ditiru oleh siswa baik dalam kegiatan pembelajaran di sekolah maupun dalam kehidupan sehari-hari. Interaksi sosial yang ada pada video animasi si Nopal diharapkan dapat mendidik seorang anak agar lebih selektif dalam mengambil manfaat dari tayangan yang dilihat. Baik dalam berprilaku maupun bersikap dalam kehidupan bermasyarakat ataupun dengan teman sebayanya khususnya anak usia 12 tahun sampai 13 tahun untuk mengembangkan potensi interaksi sosialnya. Video animasi tersebut merupakan video favorit sehingga akan mudah menarik perhatian dan diterima oleh anak berusia 12-13 tahun. Interaksi yang banyak muncul dalam video animasi si Nopal adalah interaksi sosial pada proses komunikasi yang memiliki indikasi bahwa terjadinya interaksi terdapat proses komunikasi sebagai proses pertukaran informasi.

\section{Respon anak terhadap tayangan Animasi "Si Nopal"}

Untuk mengetahui lebih lanjut respon anak terhadap tayangan Animasi "Si Nopal", penelitian ini melibatkan dua siswa sebagai subjek studi kasus sederhana yang diberikan tayangan video animasi sebanyak 10 episode selama 4-5 hari. Subjek penelitian pertama (Siswa A) merupakan seorang siswa kelas IV di SDN Tunjung 02 Lumajang, berjenis kelamin laki-laki dengan usia 12 tahun. Sedangkan subjek penelitian kedua (Siswa B) adalah seorang siwa kelas IV di SDN Tunjung 02 Lumajang, berjenis kelamin perempuan dengan usia 12 tahun. Kedua siswa kemudian diwawancara untuk mengetahui tanggapannya terhadap tayangan video animasi "Si Nopal" yang telah ditonton dan diobservasi pada kesehariannya di sekolah untuk mengetahui pola interaksi sosial yang terbentuk. Sebelum diberikan tayangan, Siswa A dan siswa B terlebih dahulu diberikan pertanyaan pengantar. Berdasarkan pertanyaan pengantar diketahui bahwa siswa A telah memiliki kebiasaan menonton video animasi di televisi. Siswa A memiliki ketertarikan terhadap beberapa judul video animasi yang di tayangkan di televisi dan rutin menontonnya saat dirumah.

Setelah diberikan tayangan video animasi "Si Nopal" sebanyak 3 episode pada hari pertama, observasi menunjukan bahwa siswa A tidak menampakkan perubahan perilaku dan interaksi sosial yang signifikan. Perubahan pola interaksi sosial mulai tampak dan terkonfirmasi dari hasil observasi ketika memasuki hari ke 2 dengan jumlah pemberian tayangan video animasi sebanyak 6 episode. Siswa A beberapakali memulai pembicaraan bersama temannya dengan menirukan nada dan intonasi khas yang sama dengan "Cute Girl" salah satu tokoh dalam animasi "Si Nopal". Perubahan tersebut dapat dikategorikan dalam interaksi kontal sosial karena mencakup cara berbicara saat bertatap muka dengan pihak lain. Perubahan pola interaksi sosial kategori kontak sosial yang merupakan dampak menonton animasi "Si Nopal" tersebut masih nampak sampai hari ke 5 walaupun intensitasnya cenderung tetap dan tidak bertambah. Perubahan lain yang tampak adalah siswa A cenderung menirukan lagu-lagu yang terdapat pada animasi "Si Nopal”. Hasil observasi menunjukan sebanyak 2-3 kali siswa A menyanyikan lagu yang sama ketika sedang berkumpul dengan teman-temannya.

Dari hasil wawancara diketahui bahwa siswa A memiliki ketertarikan pada tokoh Si Nopal dan Cute Girl. Episode yang paling disukai adalah "cita-cita Cute Girl". Siswa A juga dapat menghafal dengan baik kalimat yang terdapat dalam video animasi yang telah ditonton khususnya pada lagu "libur sekolah" yang dinyanyikan salah satu tokoh. Siswa A menyatakan bahwa dia memiliki motivasi untuk meniru aspek interaksi sosial yang ada dalam video yang ditampilkan. Siswa A juga mengungkapkan secara sadar bahwa telah mengulang-ulang naskah dialog yang ada dalam video animasi "Si Nopal".

Berdasarkan pertanyaan pengantar diketahui bahwa siswa B juga mempunyai kebiasaan sering menonton video animasi di televisi. Siswa B memiliki ketertarikan kepada video animasi yang ditayangkan di televisi dan sering menontonnya saat mempunyai waktu luang. Setelah pemberian tayangan video animasi "Si Nopal", observasi tidak menunjukan perubahan pola interaksi siswa B sampai hari ke 2. Perubahan interaksi mulai muncul pada siswa B pada hari ke 3 dengan jumlah 5 episode penayangan. Perubahan Interaksi sosial yang tampak dikategorikan dalam proses asosiatif karena siswa B terlihat beberapa kali menjelaskan dan menceritakan tayangan animasi "Si Nopal" yang telah ditontonnya kepada temannya. Siswa B memberikan berdiskusi dan menjawab pertanyaan dengan baik seputar tayangan animasi "Si Nopal" yang ditanyakan teman-temannya.

Hasil observasi tersebut dikuatkan dengan wawancara pada Siswa B yang menyatakan bahwa telah menceritakan beberapa episode animasi "Si Nopal" kepada teman-temannya dan mengajak mereka untuk menontonnya juga. Siswa B mengakui bahwa memiliki ketertarikan pada tokoh Si Nopal. Episode yang paling disukai adalah "dapat nilai jelek". Siswa B juga dapat menghafal dengan baik kalimat yang terdapat dalam video animasi yang telah ditonton khususnya pada lagu "lagu semangat 
sekolah" yang dinyanyikan salah satu tokoh. Siswa B menyatakan bahwa dia memiliki motivasi untuk meniru aspek interaksi sosial yang ada dalam video yang ditampilkan. Hasil wawancara juga mengungkapkan bahwa siswa B ternyata memiliki perubahan interaksi sosial kontak sosial dengan mengulang-ulang naskah dialog dan intonasi bicara "Cute Girl" yang ada dalam video animasi selama beraktivitas di rumah. Perubahan interaksi sosial yang terjadi pada siswa A dan siswa B merupakan salah satu contoh perubahan ke arah positif dan dapat digunakan untuk memperkaya pola interaksi mereka dengan teman dan lingkungannya ketika belajar di sekolah. Hal tersebut menguatkan hasil penelitian Ginanjar \& Saleh (2020) dan Raihan, dkk. (2020), yang menyatakan bahwa siswa dengan intensitas menonton tayangan animasi berisi konten berkualitas memiliki peningkatan interaksi sosial yang positif dengan teman sebayanya. Berdasarkan hal tersebut, tayangan video animasi hendaknya dapat dimanfaatkan guru sebagai media pembelajaran untuk mengembangkan interaksi sosial anak sehingga dapat menunjang pelaksanaan kegiatan pembelajaran. Selain itu, diperlukan pengawasan dari guru dan orang tua agar tayangan video animasi yang ditonton anak memiliki konten yang baik untuk mencegahnya dari pengaruh negatif.

Hasil penelitian ini mengungkapkan bahwa tayangan animasi video mampu mempengaruhi interaksi sosial siswa. Temuan penelitian ini sejalan dengan hasil penelitian terdahulu yang menyatakan bahwa media informasi dan komunikasi dapat berpengaruh secara positif maupun negatif terhadap perkembangan kemampuan interaksi sosial anak (Astarini, Hamid, \& Rustini, 2017). Lebih lanjut, hasil penelitian Sitinjak, Hasyim \& Yanzi (2017) mengungkapkan bahwa film kartun yang ditonton oleh anak dapat mempengaruhi perilaku mereka dalam bersosialisasi. Berdasarkan hasil analisis video animasi "Si Nopal" terdapat banyak sekali muatan contoh-contoh interaksi sosial positif yang dapat anak-anak contoh dan diterapkan dalam kehidupan sehari-hari. Hasil studi kasus yang dilakukan juga mengungkapkan bahwa semakin sering (intensif) seorang anak menonton tayangan kartun, maka akan muncul kecenderungan meniru dan mengulang apa yang ditonton dalam kehidupan sosialnya seharihari. Temuan tersebut sejalan dengan hasil penelitian terdahulu yang menyatakan semakin lama durasi dan frekuensi seorang anak dalam menonton film kartun, maka semakin tinggi tingkat peniruan (kata-kata dan perbuatan) anak dalam kehifupan sehari-hari (Putera, 2013).

\section{SIMPULAN DAN SARAN}

Berdasarkan hasil dan pembahasan dapat diketahui bahwa, video aniamasi si Nopal dapat mendukung interaksi sosial siswa. Interaksi sosial yang ada dalam video animasi si Nopal meliputi proses komunikasi, kontak sosial dan proses asosiatif. Interaksi sosial yang paling banyak muncul berupa proses komunikasi sebanyak 4 kali. Interaksi sosial tersebut dapat ditanamkan kepada anak sejak dini. 10 episode pada video animasi si Nopal hampir semuanya memiliki interaksi sosial yang dapat ditiru dan dicontohkan pada anak. Video animasi si Nopal juga dapat dimanfaatkan sebagai media pendukung dalam mengembangkan interaksi sosial anak sehingga hal ini dapat dijadikan sebagai alternatif dalam mengembangkan interaksi sosial anak. Selain itu video animasi anak si Nopal memiliki karakter yang disukai oleh siswa dan siswa tersebut bahkan ingin menirukan adegan dalam video animasi bersama teman-temannya. Siswa yang diberikan tayangan video animasi "Si Nopal" memiliki motivasi untuk meniru aspek interaksi sosial yang ada dalam video yang ditampilkan.

Hasil analisis aspek interaksi sosial dalam penelitian ini dapat dijadikan sebagai variasi dalam pembelajaran dengan memanfaatkan video animasi si Nopal sebagai media pembelajaran. Hasil penelitian ini diharapkan dapat dijadikan sebagai bahan dalam pembelajaran atau pembanding terhadap penelitian sejenis selanjutnya, sehingga penelitian yang direncanakan dapat berjalan dengan lancar dan lebih baik.

\section{UCAPAN TERIMAKASIH}

Dengan selesainya penelitian ini, kami ingin mengucapkan terima kasih kepada semua pihak yang membantu selama penelitian. Para peneliti ingin mengucapkan terima kasih kepada Fakultas Keguruan dan Ilmu Pendidikan karena memberikan izin untuk melakukan penelitian. Ucapan terima kasih juga diberikan kepada dosen dan validator dari Pendidikan Dasar, Fakultas Keguruan dan Ilmu Pendidikan, Universitas Jember yang telah bersedia membantu kelancaran dan penyempurnaan penelitian ini. 


\section{DAFTAR PUSTAKA}

Ainiyah, Q. (2017). Social Learning Theory dan Perilaku Agresif Anak dalam Keluarga. Jurnal Ilmu Syari'ah Dan Hukum, 2(1), 91-104.

Alvermann, D. E. (1991). The discussion web: A graphic aid for learning across the curriculum. Reading Teacher, 45(1), 92-99.

Astarini, N., Hamid, S. I., \& Rustini, T. (2017). Studi Dampak Tavangan Televisi Terhadap Perkembangan Perilaku Sosial Anak. Cakrawala Dini: Jurnal Pendidikan Anak Usia Dini, 8(1). $1-11$.

Bakhtiar, M. I. (2015). Pengembangan Video Ice Breaking Sebagai Media Bimbingan Konseling Dalam Meningkatkan Keterampilan Sosial. Jurnal Psikologi Pendidikan Dan Konseling: Jurnal Kajian Psikologi Pendidikan Dan Bimbingan Konseling, $1(2), \quad 150$. https://doi.org/10.26858/jpkk.v1i2.1816

Basrowi. 2005. Pengantar Sosiologi. Bogor: Ghalia Indonesia.

Bungin, B. (2009). Sosiologi Komunikasi. Surabaya: Kencana.

Gilang, L., Sihombing, R. M., \& Sari, N. (2018). Pengaruh Konteks pada Ilustrasi Buku Pendidikan Karakter terhadap Perilaku Disiplin Anak Usia Dini. Scholaria: Jurnal Pendidikan dan Kebudayaan, 8(1). 41-50.

Ginanjar, D., \& Saleh A. (2020). Pengaruh Intensitas Menonton Film Animasi "Adit Sopo Jarwo" Terhadap Interaksi Sosial Anak Sekolah Dasar. Jurnal Komunikasi Pembangunan, 18(1). 4354.

Ginting, R. L., Asiah, \& Nasution, M. I. S. (2019). Pengaruh Konseling Kelompok Pendekatan Analisis Transaksional Terhadap Interaksi Sosial Siswa dengan Teman Sebayanya. SEJ (School Educational Journal), 9(4). 326-335.

Harfiyanto, D., Utomo, C. B., \& Budi, T. (2015). Pola Interaksi Sosial Siswa Pengguna Gadget Di Sma N 1 Semarang. JESS (Journal of Educational Social Studies), 4(1), 1-5. https://doi.org/10.15294/jess.v4i1.6859

Hurst, B., Wallace, R., \& Nixon, S. (2013). The impact of social interaction on the sexual double standard. Reading Horizons, 52(4), 375-398. https://doi.org/10.1080/15534510601154413

Hernawan, D. (2010). Pengaruh Interaksi Sosial Terhadap Prestasi Belajar Matematika (Siswa Kelas IV Damar Wulan I Kepung Kediri). Skripsi. Program Studi Pendidikan Matematika.

Kurniawan, T. D. (2016). Pengaruh Penggunaan Media Video Pembelajaran Terhadap Prestasi Belajar Ilmu Pengetahuan Sosial Siswa Kelas V Sd Se-Kecamatan Gedangsari Gunungkidul. Trihayu, 3(1), 21-26.

Mertani, P., Latief, S., \& Utaminingsih, D. (2015). Peningkatan Interaksi Sosial Siswa dengan Teman Sebaya Melalui Layanan Konseling Kelompok. ALIBKIN: Jurnal Bimbingan Konseling, 4(3). $1-10$.

Muslimin, M. I. (2012). Pengaruh Penggunaan Media Pembelajaran Video Animasi Terhadap Hasil Belajar Pendidikan Kewarganegaraan Kelas II SD. Jurnal Prodi Teknologi Pendidikan, 6(1), $1-17$.

Nunik. (2013). Meningkatkan Kemampuan Interaksi Sosial Anak Melalui Metode Kerja Kelompok Pada Kelompok B TK Anata Pura Petimbe. Jurnal Bungamputi, 1(1).

Nuraida, A., Halimah, M., \& Rokhayati, A. (2014). Pengaruh Interaksi Sosial Terhadap Aktivitas Belajar Siswa Kelas Vi SD Negeri Salebu Kecamatan Mangunreja. Pedadidaktika: Jurnal Ilmiah Mahasiswa PGSD, 1(1). 1-15.

Oktaviani, N., Yusmansyah, \& Rahmayanthi, R. (2013). Peningkatan Interaksi Sosial Siswa Dengan Teman Sebaya Melalui Layanan Konseling Kelompok. Jurnal FKIP Unila, 1(1). 1-12 
Tayangan Video Animasi "Si Nopal” Untuk Mendukung Interaksi Sosial Siswa Sekolah Dasar (Ghafiruna Al Aziz, Chumi Zahroul Fitriyah, Zetti Finali)

Pebriana, P. H. (2017). Jurnal Obsesi : Jurnal Pendidikan Anak Usia Dini Analisis Penggunaan Gadget terhadap Kemampuan Interaksi Sosial. Jurnal Pendidikan Anak Usia Dini, 1(1), 8. https://doi.org/10.31004/obsesi.v1i1.26

Purnamasari, R. Y. D. (2020). Pengaruh Film Kartun Upin Ipin Terhadap Perilaku Anak Usia 7-9 Tahun. Jurnal Edukasi Nonformal, 1(2). 121-126.

Putera, A. P. (2013). Pengaruh Tayangan Film Kartun "Crayon Shinchan" Terhadap Perilaku Anak Dengan Orang Tua Pada Sekolah Dasar Yayasan Wisma Semen Gresik. Media Commonline, 1(2). 2-10.

Raihan, F., Rachman, F., Saputra, I. G., \& Afghan, M. I. Pengaruh Tayangan Kartun di TV Terhadap Kemampuan Bersosialisasi Anak. Communications 2(1). 51-66.

Routman, R. (2005). Writing essentials: Raising expectations and results while simplifying teaching. Portsmouth. NH: Heinemann.

Sitinjak, S. R., Hasyim, A., \& Yanzi, H. (2017). Pengaruh Pilihan Film Kartun Terhadap Perilaku Anak di Pekon Luas Kabupaten Lampung Barat. Jurnal Beranda, 5(8). 1-15.

Soekanto, S. (2017). Sosiologi Suatu Pengantar. Edisi Revisi. Jakarta: Raja Grafindo Persada.

Sudjana. (2009). Penilaian Hasil Proses Belajar Mengajar. Bandung: PT Remaja Rosdakarya.

Triwardani, R., \& Wicandra, O. B. (2007). Kajian Kritis Praktik Anak Menonton Film Kartun di Televisi dalam Aktifitas Keseharian di Banyuwangi. Jurnal Nirmana, 9(1). 46-56.

Vacca, R.T., Vacca, J.L., \& Mraz, M. (2011). Content area reading: Literacy and learning across the curriculum (10th ed.). Boston: Pearson. 